\title{
Micro finance intervention and its influence on decision making pattern on beneficiaries- A study on NGOs MF programme
}

Author for Correspondence :

\section{BABITA SHARMA}

Krishi Vigyan Kendra, KAMRUP (ASSAM) INDIA

Email : babita_s06@yahoo.co.in
ABSTRACT : Decision making is a capacity of individual which influence their lives and it enables to realize their identity and power in all spheres of life. Access to credit without physical collateral through various entities as alternative micro finance institutions plays a great role in the lives of millions of poor people particularly women in terms of creating self employment across the world. Financial capabilities and participation in income-generating activities of women relatively strengthen their bargaining position within the household thereby enhance decision making capacity of women in many cases. This research article depicts purposively selected two NGOs micro finance (mf) impact in decision making capacity of women after micro finance intervention at household and community level. Study was conducted in Sonitpur and Lakhimpur districts of Assam covering 945 numbers. of beneficiaries. Survey method was applied to gather the information. NGOs microfinance programme has helped to raised employment status of women in study area, unrelated to the matter of individual employment or in association with other family members. The change of raising employment is more pronounced about 97 per cent among women, which in turn found positive impact on capacity of decision making. Regression co-efficient of employment status of women after Mf intervention (ESWAMf) appear significantly positive in all selected categories of decision making, this may be due to fact that employment leads to possession over income, knowledge, awareness, self confidence and exposure to outside world.

KEY WORDS: Micro finance, Non-government organization (NGO), Self employment, Women empowerment, Decision making

- HOW TO CITE THIS PAPER : Sharma, Babita (2016). Micro finance intervention and its influence on decision making pattern on beneficiaries- A study on NGOs MF programme. Asian J. Home Sci., 11 (2) : 306-313, DOI: 10.15740/HAS/AJHS/11.2/306-313. 